\title{
A SUSTAINED INCREASE OF MICROSOMAL HEME OXYGENASE ACTIVITY FOLLOWING TREATMENT OF RATS WITH BACILLUS CALMETTE-GUERIN AND CORYNEBACTERIUM PARVUM: ITS POSSIBLE RELATION TO THE DECREASE OF CYTOCHROME P-450 CONTENT
}

\author{
Yoichi Matsuura, Hiroyuki Watanabe, Teruo Fukuda, ${ }^{*}$ Takemi Yoshida and Yukio \\ KUROIWA**
}

Department of Hygienic Chemistry, Showa College of Pharmaceutical Sciences, ${ }^{*}$ 5-1-8 Tsurumaki, Setagaya-ku, Tokyo, 154, Japan and Department of Biochemical Toxicology, School of Pharmaceutical Sciences, Showa University, ${ }^{* *}$ 1-5-8 Hatanodai, Shinagawa-ku, Tokyo, 142, Japan

(Received January 10, 1985)

The alterations of various enzymes responsible for drug metabolism and heme metabolism were examined in the liver of female rats treated with Bacillus Calmette-Guerin (BCG) and Corynebacterium parvum (CP). Hepatic drug metabolizing enzyme activities and microsomal cytochrome P-450 and $\mathrm{b}_{5}$ content were significantly decreased for up to 15 and $10 \mathrm{~d}$ by a single i.v. administration of BCG and $\mathrm{CP}$, respectively. In contrast, microsomal heme oxygenase activity was markedly increased after BCG and CP treatment and the increased enzyme activity was sustained in parallel with the decrease of drug metabolizing enzymes.

Both BCG and CP also caused a significant decrease of $\delta$-aminolevulinic acid synthetase activity shortly after their administrations. The decreased enzyme activity returned to normal levels by $12 \mathrm{~h}$ after the treatment of rats with BCG and CP. In addition, hepatosplenomegaly was observed in BCG and CP treated rats. Dose related changes of these microsomal enzymes were seen following the administration of BCG and CP. Additionally, there were sex differences in the effects of BCG and CP on the alteration of microsomal enzymes, female rats being more sensitive than male rats. These results suggest that the decrease of cytochrome P-450 and $b_{5}$ content and drug metabolizing enzyme activities by BCG and CP could be related, at least in part, to the prolonged increase of heme oxygenase activity, that may lead to the increased breakdown of heme available for the synthesis of these hemoproteins.

Keywords — bacillus calmette-guerin; Corynebacterium parvum; heme oxygenase; cytochrome $\mathrm{P}-450 ; \delta$-aminolevulinic acid synthetase

\section{INTRODUCTION}

Bacillus Calmette-Guerin (BCG) and Corynebacterium parvum (CP), which are potent nonspecific immunostimulants, have been used experimentally and clinically as immunotherapeutic agents with malignant diseases. ${ }^{1,2)}$ It has been shown that hepatic microsomal cytochrome P-450 content and its-linked drug metabolizing enzyme activities are depressed for a prolonged time in the rat by immunoadjuvants treatment such as $\mathrm{BCG},{ }^{3)} \mathrm{CP},{ }^{4-6)}$ interferon, ${ }^{7}$ interferon inducing agents ${ }^{8,9)}$ and bacterial cell walls com- ponents. ${ }^{10)}$

Azhary et al. ${ }^{11)}$ have recently shown that polyribonucleic acid and tilorone also produce the changes in regulatory enzymes involved in heme biosynthetic and degradative pathway in the liver, such as the decrease of $\delta$-aminolevulinic acid (ALA) synthetase and the induction of heme oxygenase. Furthermore, they reported that turnover rates of heme moiety of cytochrome $\mathrm{P}-450$ is faster in the polyribonucleic acid or tilorone treated rats than the control. ${ }^{12)}$ It is also shown that some immunopotentiators, 
such as OK-432, produce the increase of heme oxygenase $^{13)}$ and the decrease of drug metabolizing enzyme activities. ${ }^{14)}$ These results suggest that hepatic microsomal cytochrome P-450 content and its-linked drug metabolism could be affected by the changes of heme metabolizing enzyme activities.

Considering these facts, this investigation was designed to examine the effects of BCG and CP on hepatic ALA synthetase, heme oxygenase activities as well as drug metabolizing enzyme activities.

\section{MATERIALS AND METHODS}

Chemicals and Immunopotentiators - Nicotinamide adenine dinucleotide phosphate (NADPH), nicotinamide adenine dinucleotide (NADH), hemin and pyridoxal phosphate were obtained from Sigma Chemical Co., glucose 6 phosphate and glucose 6-phosphate dehydrogenase were obtained from Oriental Yeast Co. All other chemicals used were of reagent grade available commercially.

Dried BCG vaccine was obtained from Japan BCG Laboratory. CP (Corynebacterium parvum C-7 012484) was kindly donated by Dr. T. Arai, Department of Microbiology, Showa College of Pharmaceutical Sciences. CP was cultivated in Brain Heart Infusion (DIFCO Laboratories) at $37^{\circ} \mathrm{C}$ for $2 \mathrm{~d}$ by the method of Saino et al. ${ }^{15)}$ The cells were collected by centrifugation at 8000 rpm for $20 \mathrm{~min}$. After washing twice with $0.9 \%$ $\mathrm{NaCl}$ solution, the cells were suspended in the $0.9 \% \mathrm{NaCl}$ solution and then killed by heating at $70{ }^{\circ} \mathrm{C}$ for $30 \mathrm{~min}$. After washing with $0.9 \%$ $\mathrm{NaCl}$ solution, the cells were collected by centrifugation at $8000 \mathrm{rpm}$ for $20 \mathrm{~min}$ and lyophilized.

Animals and Treatment - Male and female Sprague-Dawley rats, weighing 150-160 g at the beginning of the experiments, were used in this study. They were fed a commercial diet ad libitum. BCG and CP were suspended in sterile $0.9 \% \mathrm{NaCl}$ solution and administered to experimental rats through the tail vein at various doses in a volume of $0.2 \mathrm{ml}$. Control rats of BCG ex- periments were always injected with a solution of $15 \%$ sodium glutamate in $0.9 \% \mathrm{NaCl}$ solution, correponding to the amount of the glutamate contained in the BCG vaccine.

Tissue Preparation - The rats were sacrificed by decapitation and their livers were removed. The removed livers were weighed immediately and were perfused with $0.9 \% \mathrm{NaCl}$ solution. For the assay of ALA synthetase, a portion of nonperfused liver was homogenized in 3 vols. of 10 $\mathrm{mM}$ Tris- $\mathrm{HCl}$ buffer ( $\mathrm{pH} 7.4)$ containing $0.9 \%$ $\mathrm{NaCl}$ and $0.5 \mathrm{~mm}$ ethylenediaminetetraacetic acid (EDTA). The remaining perfused liver was homogenized with 9 vols. of $0.25 \mathrm{M}$ sucrose. The homogenate was centrifuged at $9000 \mathrm{~g}$ for $15 \mathrm{~min}$ and the resulting supernatant was centrifuged at $105000 \boldsymbol{g}$ for $1 \mathrm{~h}$. The pellet was suspended in $0.1 \mathrm{M}$ phosphate buffer ( $\mathrm{pH} 7.4)$ and used as enzyme sources for the determination of heme oxygenase, cytochrome P-450, cytochrome $b_{5}$ and drug metabolizing enzyme activities.

Enzyme Assays - Heme oxygenase activity was assayed by the method of Tenhunen et al. ${ }^{16)}$ by determining the formation of bilirubin in the presence of cytosolic biliverdin reductase with and without the addition of NADPH. ALA synthetase activity was assayed by the method of Marver et al. ${ }^{17)}$ using a total liver homogenate as enzyme source. The ALA produced was determined colorimetrically after condensation with acetylacetone and isolation of the pyrrole compound formed on the Dowex-1-acetate column. ${ }^{18)}$ Cytochrome P-450 and $b_{5}$ contents were determined by the method of Omura and Sato. ${ }^{19)}$ Aminopyrine demethylase activity was measured $^{20)}$ by determining the formaldehyde released according to the method of Nash. ${ }^{21)}$ Aniline hydroxylase activity was determined by the method of Imai et $a l^{22)}$ Protein content was determined by the method of Lowry et al. ${ }^{23}$ ) using bovine serum albumin as the standard.

\section{RESULTS}

Effects of BCG and CP on Liver Weight, Spleen Weight and Protein Content of Hepatic Microsomes 


\section{of Female Rats}

As shown in Table I, administration of BCG $(40 \mathrm{mg} / \mathrm{kg})$ and CP $\left(30 \mathrm{mg} / \mathrm{m}^{2}, 4.9 \mathrm{mg} / \mathrm{kg}\right)$ to female rats resulted in increase of liver and spleen weight. Liver weights of BCG and CP treated rats reached maximum of 117 and $114 \%$ of the control at $6 \mathrm{~d}$ after the treatments, respectively. Spleen weights of BCG and CP treated rats were significantly increased and reached maximum of 206 and $197 \%$ of the control at 10 $\mathrm{d}$ after the treatments, respectively. Levels of hepatic microsomal protein of BCG and CP treated rats were not significantly different from the control throughout the experimental periods. Time Course of the Effect of BCG on Microsomal Drug Metabolizing Enzyme Systems and Heme

\section{metabolizing Enzymes}

Fig. 1 shows the time course of the effect of a single administration of BCG to female rats at a dose of $40 \mathrm{mg} / \mathrm{kg}\left(6-7 \times 10^{8}\right.$ organisms $\left./ \mathrm{m}^{2}\right)$ i.v. on hepatic microsomal aminopyrine demethylase and aniline hydroxylase activities and cytochrome P-450 and $\mathrm{b}_{5}$ contents. The BCG dosage approximates that administered to rats by Farquhar et $a l^{3)}$ and to man by scarification in the immunotherapy of malignant melanoma. ${ }^{24)}$ Aminopyrine demethylase and aniline hydroxylase activities expressed in $\mathrm{mg}$ microsomal protein were significantly decreased shortly after the administration of BCG and reached minimum at $3 \mathrm{~d}$. The depressed enzyme activities were sustained for $15 \mathrm{~d}$ after BCG administra-

TABLE I. Effect of BCG and CP on Liver Weight, Spleen Weight and Protein Content of Hepatic Microsomes of Female Rats

\begin{tabular}{|c|c|c|c|c|}
\hline Treatment & $\frac{\text { Time }}{(\mathrm{d})}$ & $\frac{\text { Liver weight }}{(\mathrm{g} / 100 \mathrm{~g} \text { body weight })}$ & $\frac{\text { Spleen weight }}{(\mathrm{g} / 100 \mathrm{~g} \text { body weight })}$ & $\begin{array}{l}\text { Hepatic microsomal } \\
\text { protein } \\
\text { (mg/g liver })\end{array}$ \\
\hline \multicolumn{5}{|l|}{$\left.\mathrm{BCG}^{a}\right)$} \\
\hline Control & 3 & $3.97 \pm 0.13$ & $0.317 \pm 0.037$ & $13.38 \pm 1.04$ \\
\hline Treated & & $4.26 \pm 0.16$ & $0.399 \pm 0.061$ & $13.49 \pm 0.96$ \\
\hline Control & 6 & $3.86 \pm 0.11$ & $0.324 \pm 0.013$ & $13.69 \pm 0.79$ \\
\hline Treated & & $4.52 \pm 0.18^{b)}$ & $0.447 \pm 0.025^{b)}$ & $14.23 \pm 1.08$ \\
\hline Control & 10 & $3.95 \pm 0.15$ & $0.350 \pm 0.027$ & $13.70 \pm 1.66$ \\
\hline Treated & & $4.39 \pm 0.32$ & $0.721 \pm 0.091^{b)}$ & $14.54 \pm 1.25$ \\
\hline Control & 15 & $4.11 \pm 0.14$ & $0.374 \pm 0.022$ & $13.23 \pm 1.20$ \\
\hline Treated & & $4.21 \pm 0.20$ & $0.641 \pm 0.097^{b)}$ & $14.14 \pm 1.73$ \\
\hline \multicolumn{5}{|l|}{$\mathrm{CP}^{a)}$} \\
\hline Control & 3 & $3.98 \pm 0.18$ & $0.295 \pm 0.018$ & $14.46 \pm 1.26$ \\
\hline Treated & & $4.11 \pm 0.11$ & $0.351 \pm 0.032^{b)}$ & $14.08 \pm 1.37$ \\
\hline Control & 6 & $3.68 \pm 0.07$ & $0.283 \pm 0.011$ & $14.48 \pm 0.62$ \\
\hline Treated & & $\left.4.19 \pm 0.09^{b}\right)$ & $\left.0.361 \pm 0.031^{b}\right)$ & $14.29 \pm 0.67$ \\
\hline Control & 10 & $4.02 \pm 0.13$ & $0.269 \pm 0.020$ & $14.83 \pm 0.94$ \\
\hline Treated & & $4.17 \pm 0.16$ & $0.528 \pm 0.039^{b)}$ & $15.49 \pm 0.70$ \\
\hline Control & 15 & $3.99 \pm 0.19$ & $0.289 \pm 0.041$ & $13.20 \pm 1.02$ \\
\hline Treated & & $4.12 \pm 0.18$ & $0.449 \pm 0.062^{b)}$ & $13.60 \pm 0.95$ \\
\hline
\end{tabular}

Each value is the mean $\pm S$.E. of four rats. Average body weights of the control, BCG-treated and CPtreated rats on 0 were $163 \pm 6 \mathrm{~g}, 167 \pm 4 \mathrm{~g}$ and $170 \pm 4 \mathrm{~g}$, respectively.

a) Female Sprague-Dawley rats were sacrificed at the time indicated after BCG $(40 \mathrm{mg} / \mathrm{kg})$ or CP (30 $\mathrm{mg} / \mathrm{m}^{2}$ ) i.v. injection and determined liver weight, spleen weight and hepatic microsomal protein. Significantly different from the corresponding control, $p<0.05$. 
tion. Likewise, microsomal cytochrome P-450 and $b_{5}$ contents were decreased throughout the experimental period. When the enzyme activities and hemoprotein content were expressed in $\mathrm{g}$ wet weight of liver rather than $\mathrm{mg}$ microsomal protein, the extents of the decrease of these parameters were more profound. These results are well compatible to those reported by other investigators. ${ }^{3)}$

Under the same experimental conditions, hepatic heme oxygenase and ALA synthetase activities were also determined. As shown in Fig. 2, heme oxygenase activity was significantly increased shortly after the administration of BCG and reached its maximum of 2.7 -fold increase at $3 \mathrm{~d}$. The increased heme oxygenase activity seems to be closely related to the decrease of microsomal cytochrome P-450 and $b_{5}$ contents and drug metabolizing enzyme activities throughout the experimental periods. On the other hand, mitochondrial ALA synthetase activity was decreased soon after BCG treatment and the decreased enzyme activity was sustained for up to $12 \mathrm{~h}$, and thereafter the enzyme activity returned
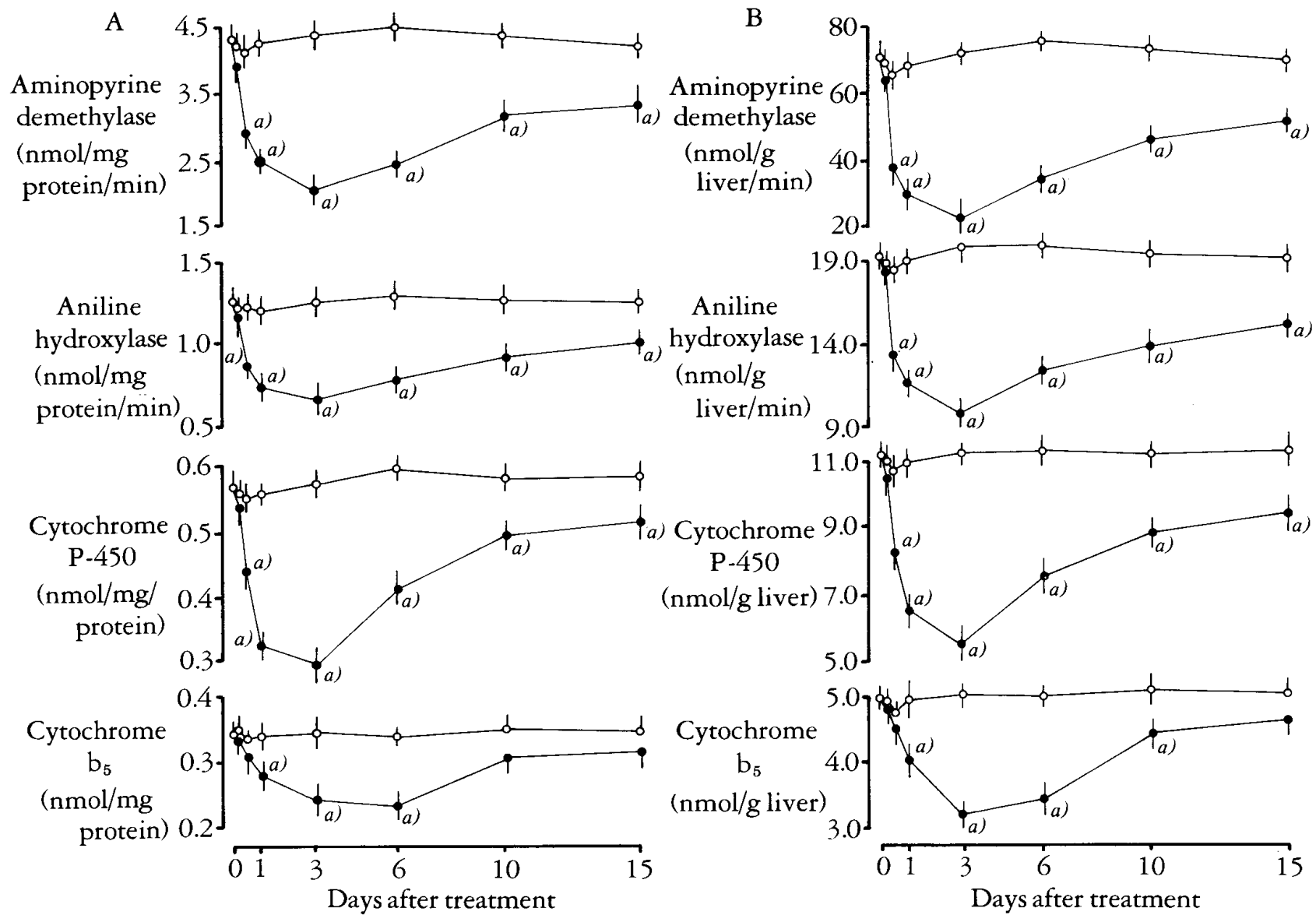

FIG. 1. Time Course of the Effect of a Single Administration of BCG on Hepatic Microsomal Drug Metabolizing Enzyme Activities and Cytochrome Content

Female Sprague-Dawley rats were sacrificed at the time indicated after BCG at a dose of $40 \mathrm{mg} / \mathrm{kg}$ i.v. injection through the tail vein and determined aminopyrine demethylase, aniline hydroxylase, cytochrome $P-450$ and cytochrome $b_{5} .(O)$, enzyme activity in control rats $(n=5) ;(\bullet)$, enzyme activity in treated rats $(n=6)$. A, enzyme activity expressed as microsomal protein; $B$, enzyme activity expressed as $g$ wet weight of liver. a) Significantly $(p<0.05)$ different from the corresponding control. 
to normal levels.

Time Course of the Effect of CP on Microsomal Drug Metabolizing Enzyme Systems and Heme Metabolizing Enzymes

Alterations of hepatic microsomal aminopyrine demethylase and aniline hydroxylase activities and cytochrome P-450 and $b_{5}$ contents were determined in the female rats by other immunoadjuvant, $C P\left(30 \mathrm{mg} / \mathrm{m}^{2}, 4.9 \mathrm{mg} / \mathrm{kg}\right)$ i. $v$. treatment and the results are shown in Fig. 3.

The changed patterns of the microsomal hemoprotein contents and enzyme activities in $\mathrm{CP}$-treated rats were almost similar to those of the BCG-treated rats. However, the duration of the depressing effect of $\mathrm{CP}$ on these hemoproteins and enzyme activities was rather shortened as compared to that of BCG. CP treatment also resulted in the increase of hepatic heme oxygenase activity. As shown in Fig. 4, heme oxygenase activity was increased rapidly after treatment of rats with CP and the increased enzyme activity was sustained for $10 \mathrm{~d}$. Additionally, CP showed a rapid and short-lived depressive effect on hepatic ALA synthetase, as shown in Fig. 4.

Dose Response of the Effects of $B C G$ and $C P$ on Microsomal Enzymes

Dose response of the effects of these two immunopotentiators on hepatic mictosomal enzymes was examined, and the results are shown in Table II. Aminopyrne demethylase activity and cytochrome P-450 content tended to decrease and heme oxygenase activity tended to increase with the increasing doses of both BCG and $\mathrm{CP}$ in the female rats. An excellent inverse correlation also existed between heme oxygenase activity and cytochrome P-450 content (correlation coefficient, $r=-0.94$ ).

Sex Differences of the Effects of $B C G$ and $C P$ on Microsomal Enzymes

There is evidence that male and female rats respond differently to BCG and $\mathrm{CP}$ with respect to the decrease of drug metabolizing enzymes;

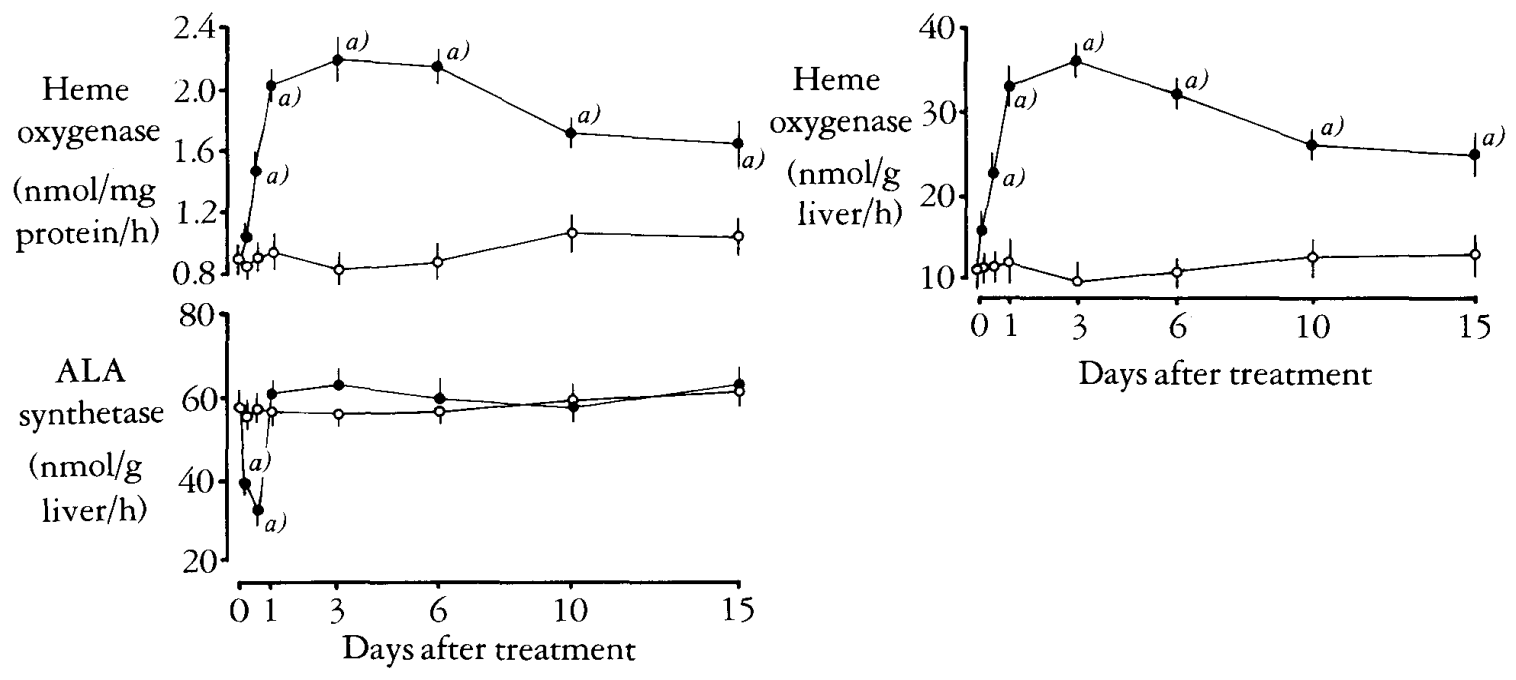

FIG. 2. Time Course of the Effect of a Single Administration of BCG on Hepatic Heme Oxygenase and ALA Synthetase Activities

Female Sprague-Dawley rats were sacrificed at the time indicated after BCG at a dose of $40 \mathrm{mg} / \mathrm{kg}$ i.v. injection through the tail vein and determined heme oxygenase and ALA synthetase. $(O)$, enzyme activity in control rats $(n=5)$; $(\bullet)$, enzyme activity in treated rats $(n=6)$. Heme oxygenase activity was expressed as microsomal protein and $g$ wet weight of liver. a) Significantly $(p<0.05)$ different from the corresponding control. 
female rats being more sensitive than male rats. ${ }^{3)}$ Considering these facts, experiments were carried out to examine whether there are any differences in the effects of BCG and CP on heme oxygenase as well as drug metabolizing enzymes.

As shown in Table III, the extent of the decrease of cytochrome P-450 content and aminopyrine demethylase activity following either BCG or CP treatment were more pronounced in female rats as compared to male rats. The results well coincided with those of the previous findings. ${ }^{3)}$ In accordance with this fact, the increased
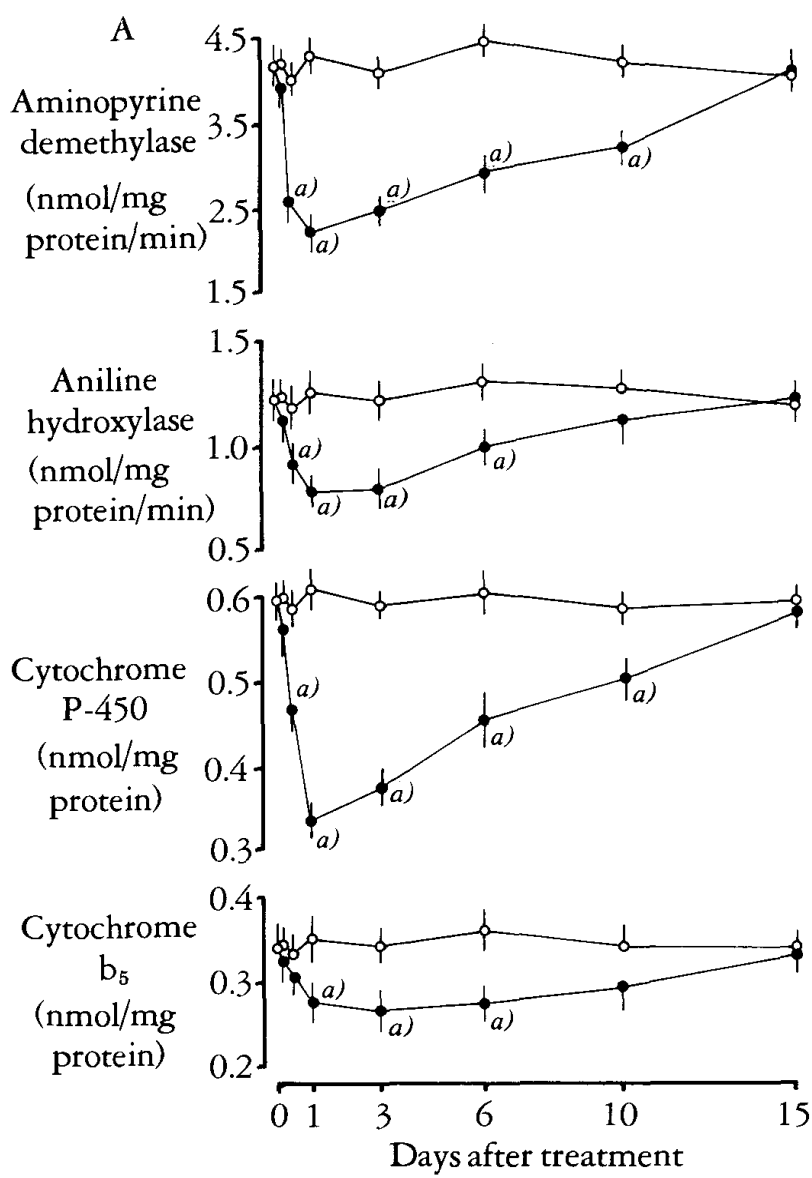

heme oxygenase activity after tratment with BCG or CP was only seen in female rats, but not or less extensive in male rats. The results indicate that both BCG and CP produce the decrease of cytochrome P-450 and aminopyrine demethylase activity accompanying with the increase of heme oxygenase activity.

\section{DISCUSSION}

The present investigation has confirmed that a single administration of BCG and CP to female rats resuted in the depression of hepatic
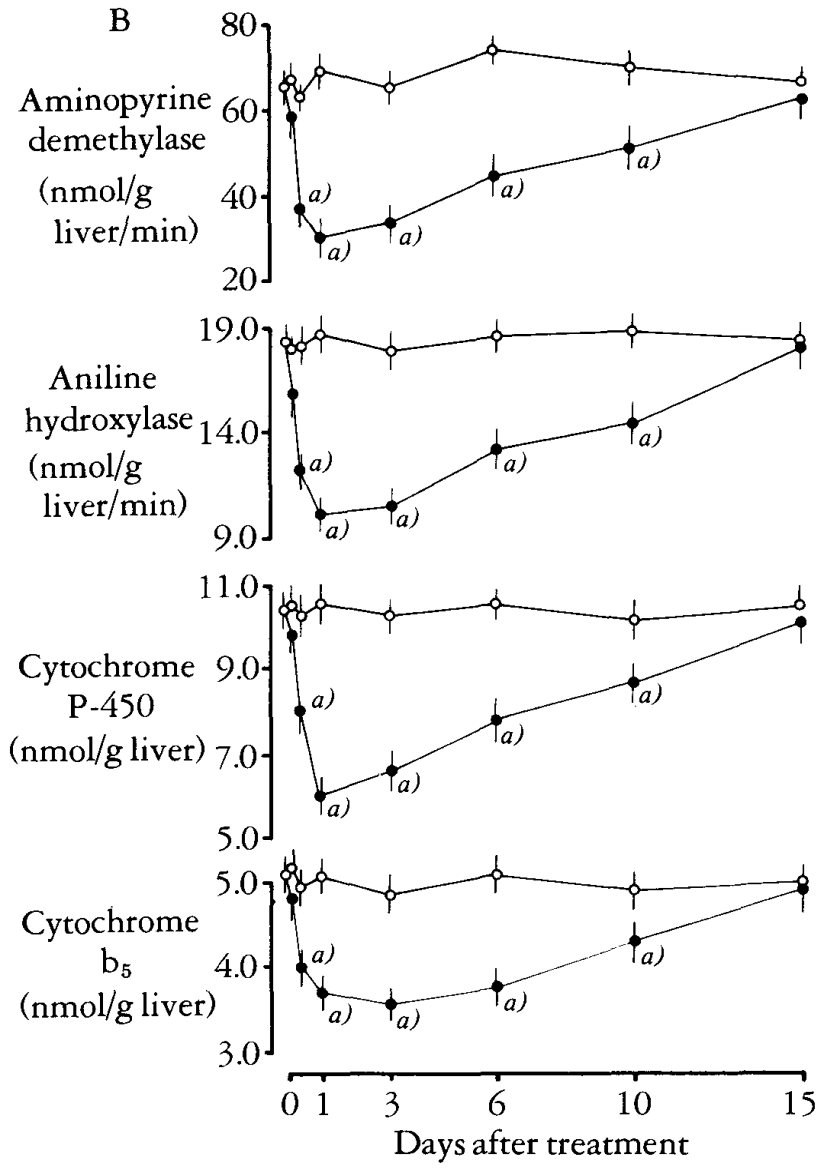

FIG. 3. Time Course of the Effect of a Single Administration of CP on Hepatic Microsomal Drug Metabolizing Enzyme Activities and Cytochrome Content

Female Sprague-Dawley rats were sacrificed at the time indicated after CP at a dose of $30 \mathrm{mg} / \mathrm{m}^{2} i . v$. injection through the tail vein and determined aminopyrine demethylase, aniline hydroxylase, cytochrome $P-450$ and cytochrome $b_{5} .(O)$, enzyme activity in control rats $(n=5) ;(0)$, enzyme activity in treated rats $(n=6)$. $A$, enzyme activity expressed as microsomal protein; $B$, enzyme activity expressed as $g$ wet weight of liver. a) Significantly $(p<0.05)$ different from the corresponding control. 
microsomal cytochrome $\mathrm{P}-450$ and $\mathrm{b}_{5}$ content and drug metabolizing enzyme activities. The depression of microsomal enzyme activities in female rats sustained for more than 15 and $10 \mathrm{~d}$ in BCG-treated and CP-treated rats, respectively. Such a prolonged depression of microsomal enzyme activities observed after a single administration of $\mathrm{BCG}$ and $\mathrm{CP}$ to rats is a very unique phenomenon, usually not seen by the chemicals administration. The present results are well compatible to those reported by other investigators. ${ }^{3-6)}$ Farquhar et $a l_{.}{ }^{3)}$ have pointed out that the depression of the microsomal enzyme activities by BCG and CP is not simply due to the systemic toxicity of the agents and adjuvantinduced arthritogenic disease.

This study has also revealed that both BCG and $\mathrm{CP}$ produce a significant increase of heme oxygenase activity. Additionally, both BCG and CP temporary reduced hepatic ALA synthetase (Fig. 2,4) activity. These facts indicate that both BCG and CP would perturb hepatic heme

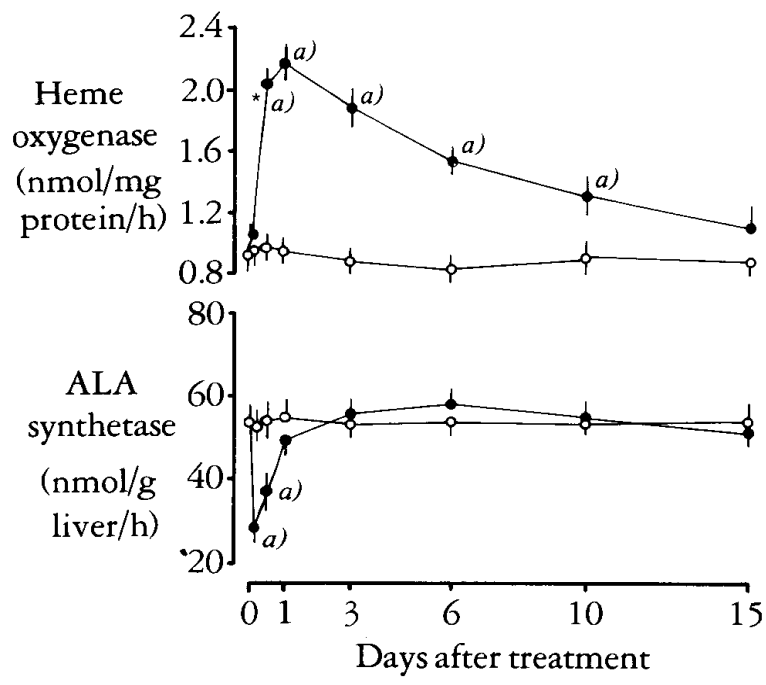

metabolism.

It should be pointed out that there is an inverse relationship between the decrease of cytochrome P-450 content and the increase of heme oxygenase activity following BCG and CP treatment. Such as inverse relationship between the decrease of cytochrome P-450 content and the increase of heme oxygenase activity has been shown by the treatment of animals with several agents including heavy metals, ${ }^{25)}$ and postulated to be a possible mechanism for the decrease of cytochrome P-450. We have also found this relation between cytochrome P-450 and heme oxygenase in thioacetamide-treated rat liver, ${ }^{26)}$ in tumor-bearing rat liver ${ }^{27)}$ and in regenerating rat liver. ${ }^{28)}$ Some immunopotentiators ${ }^{13)}$ and interferon inducers ${ }^{11)}$ have been also demonstrated to increase heme oxygenase in experimental animals. It has been shown that the turnover of cytochrome P-450 heme moiety is markedly enhanced under the experimental conditions where heme oxygenase activity is induced by

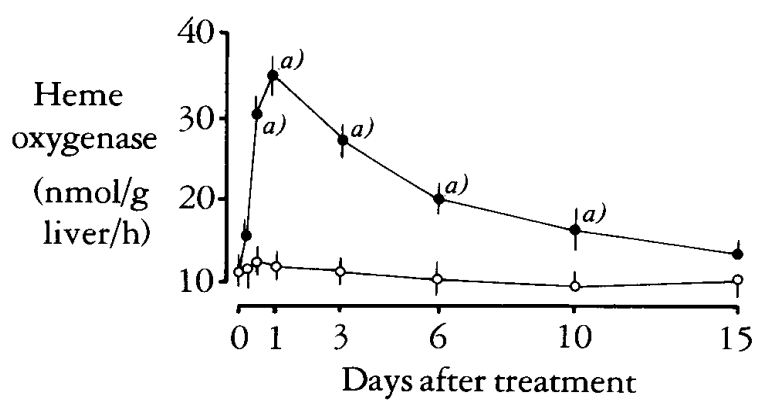

FIG. 4. Time Course of the Effect of a Single Administration of CP on Hepatic Heme Oxygenase and ALA Synthetase Activities

Female Sprague-Dawley rats were sacrificed at the time indicated after CP at a dose of $30 \mathrm{mg} / \mathrm{m}^{2}$ i.v. injection through the tail vein and determined heme oxygenase and $A L A$ synthetase. (O), enzyme activity in control rats $(n=5)$; $(\bullet)$, enzyme activity in treated rats $(n=6)$. Heme oxygenase activity was expressed as microsomal protein and $g$ wet weight of liver. $a)$ Significantly $(p<0.05)$ different from the corresponding control. 
$\mathrm{Cd}^{29)}$ or interferon-inducing agents. ${ }^{12)}$ Thus, such an increased breakdown of heme during the induction of heme could lead, if not all, to the decrease of cytochrome P-450 content, thereby decreasing heme concentration available for the formation of the hemoprotein. The extents of the increase of heme oxygenase and the decrease of cytochrome P-450 seen on the administrations of both BCG and CP to female rats were dose dependent. In addition, male rats did not respond to both BCG and CP with respect to the increase of heme oxygenase and the decrease of cytochrome P-450 content. The results also suggest that the increase of heme oxygenase ac- tivity owing to the treatment with both BCG and $\mathrm{CP}$ could be related to the decrease of cytochrome P-450 content.

However, it can not be ruled out that both BCG and CP can directly affect on cytochrome $\mathrm{P}-450$ synthesis.

In this respect, further detailed studies will be required.

Because of the importance of immunotherapy for malignant diseases, the present findings would provide further information on the effects of immunostimulators on hepatic heme metabolizing enzymes in relation to the decrease of cytochrome P-450 content and the related

TABLE II. Dose Response of BCG and CP on Hepatic Microsomal Aminopyrine Demethylase, Cytochrome P-450 and Heme Oxygenase

\begin{tabular}{|c|c|c|c|}
\hline Treatment & $\frac{\text { Aminopyrine demethylase }}{(\mathrm{nmol} / \mathrm{mg} \text { protein } / \mathrm{min})}$ & $\frac{\text { Cytochrome } \mathrm{P}-450}{(\mathrm{nmol} / \mathrm{mg} \text { protein })}$ & $\frac{\text { Heme oxygenase }}{(\mathrm{nmol} / \mathrm{mg} \text { protein } / \mathrm{h})}$ \\
\hline \multicolumn{4}{|l|}{$\left.\mathrm{BCG}^{a}\right)$} \\
\hline \multirow[t]{2}{*}{ Control } & $4.627 \pm 0.191$ & $0.560 \pm 0.010$ & $0.973 \pm 0.127$ \\
\hline & $(49.640 \pm 0.908)$ & $(7.984 \pm 0.132)$ & $(12.880 \pm 1.049)$ \\
\hline \multirow[t]{2}{*}{$10 \mathrm{mg} / \mathrm{kg}$} & $3.645 \pm 0.309)^{b)}$ & $\left.0.526 \pm 0.020^{b}\right)$ & $1.681 \pm 0.205^{b)}$ \\
\hline & $(42.830 \pm 5.562)$ & $(7.050 \pm 0.433)^{b)}$ & $\left.(25.365 \pm 3.141)^{b}\right)$ \\
\hline \multirow{2}{*}{$20 \mathrm{mg} / \mathrm{kg}$} & $\left.3.300 \pm 0.230^{b}\right)$ & $\left.0.466 \pm 0.043^{b}\right)$ & $2.069 \pm 0.264 b)$ \\
\hline & $\left.(32.822 \pm 4.293)^{b}\right)$ & $\left.(4.963 \pm 0.433)^{b}\right)$ & $\left.(29.893 \pm 4.540)^{b}\right)$ \\
\hline \multirow[t]{2}{*}{$40 \mathrm{mg} / \mathrm{kg}$} & $1.793 \pm 0.114^{b)}$ & $0.350 \pm 0.036^{b)}$ & $2.148 \pm 0.306^{b)}$ \\
\hline & $\left.(26.141 \pm 8.160)^{b}\right)$ & $\left.(4.493 \pm 0.030)^{b}\right)$ & $(32.029 \pm 5.299)^{b)}$ \\
\hline \multirow[t]{2}{*}{$60 \mathrm{mg} / \mathrm{kg}$} & $1.454 \pm 0.136^{b)}$ & $0.340 \pm 0.008^{b)}$ & $2.386 \pm 0.359)^{b)}$ \\
\hline & $\left.(23.016 \pm 2.458)^{b}\right)$ & $\left.(3.979 \pm 0.669)^{b}\right)$ & $\left.(36.096 \pm 0.495)^{b}\right)$ \\
\hline \multicolumn{4}{|r|}{ ז } \\
\hline \multirow{2}{*}{ Control } & $4.273 \pm 0.006$ & $0.571 \pm 0.011$ & $0.971 \pm 0.008$ \\
\hline & $(48.598 \pm 0.099)$ & $(7.077 \pm 0.083)$ & $(12.118 \pm 1.163)$ \\
\hline \multirow[t]{2}{*}{$10 \mathrm{mg} / \mathrm{m}^{2}$} & $3.543 \pm 0.379^{b)}$ & $0.518 \pm 0.066$ & $1.356 \pm 0.061^{b)}$ \\
\hline & $(44.728 \pm 6.578)$ & $(6.861 \pm 1.036)$ & $(17.383 \pm 0.875)^{b)}$ \\
\hline \multirow[t]{2}{*}{$20 \mathrm{mg} / \mathrm{m}^{2}$} & $3.282 \pm 0.059^{b)}$ & $0.491 \pm 0.022^{b)}$ & $1.522 \pm 0.026^{b)}$ \\
\hline & $(41.300 \pm 1.255)^{b)}$ & $(6.468 \pm 0.244)^{b)}$ & $(20.199 \pm 0.718)^{b)}$ \\
\hline \multirow[t]{2}{*}{$30 \mathrm{mg} / \mathrm{m}^{2}$} & $\left.2.911 \pm 0.198^{b}\right)$ & $0.384 \pm 0.033^{b)}$ & $2.145 \pm 0.300^{b)}$ \\
\hline & $(35.827 \pm 0.403)^{b)}$ & $\left.(5.082 \pm 0.322)^{b}\right)$ & $(25.179 \pm 3.483)^{b)}$ \\
\hline \multirow[t]{2}{*}{$40 \mathrm{mg} / \mathrm{m}^{2}$} & $1.245 \pm 0.123^{b}$ & $0.295 \pm 0.025^{b)}$ & $2.569 \pm 0.167^{b)}$ \\
\hline & $(23.753 \pm 1.367)^{b)}$ & $(3.752 \pm 0.274)^{b)}$ & $(32.958 \pm 2.002)^{b)}$ \\
\hline
\end{tabular}
liver.

Each value is the mean \pm S.E. of four rats. Figures in parentheses represent activity of $g$ wet weight of

a) Female Sprague-Dawley rats were injected i.v. at a various dose levels of BCG or CP and sacrificed at 3 d after the treatment. b) Significantly $(p<0.05)$ different from the corresponding control. 
enzyme activities.

Because, decrease of cytochrome P-450 containing drug metabolising enzymes in BCG- and $\mathrm{CP}$-treated animals could lead to a modification of metabolism of chemotherapeutic drugs concurrently administered and alteration of their pharmacological ability. Based on these findings, further detailed studies will be necessary to examine whether such an inverse relationship between the increase of heme oxygenase activity and the decrease of cytochrome $\mathrm{P}-450$ content is a generalized phenomenon seen in non-specific immunostimulators administration.

Acknowledgement We would like to thank Dr. K. Koyama of National Cancer Center Research Institute for the kind service in providing a convenient supply of Corynebacterium parvum.

\section{REFERENCES}

1) L. Milas and M. T. Scott: Antitumor activity of Corynebacterium parvum, Adv. Cancer Res., 26, 257-306 (1978).

2) R. C. Reed: Increased regression of liver and lung metastases (M'TS) of disseminated melanoma (DM) by the addition of corynebacterium parvum (CP) to the imidazole carboxamide (DTIC), nitrosourea (MECCNU) and BCG regimen (DMB), Proc. Am. Assoc. Cancer Res., 17, 214 (1976).

3) D. Farquhar, T. L. Loo, J. U. Gutterman, E. M. Hersh and M. A. Luna: Inhibition of drug-metabolizing enzymes in the rat after Bacillus Calmette-Guerin treatment, Biochem. Pharmacol., 25, 1529-1535 (1976).

4) D. Farquhar, J. A. Benvenuto, N. Kuttesch and T. L. Loo: Inhibition of hepatic drug metabolism in the rat after Corynebacterium parvum treatment, Biochem. Pharmacol., 32, 1275-1280 (1983).

5) L. F. Soyka, W. G. Hunt, S. E. Knight and R. S. Foster Jr: Decreased liver and lung drug-metabolizing activity

TABLE III. Differential Effect of BCG and CP on Hepatic Microsomal Aminopyrine Demethylase, Cytochrome P-450 and Heme Oxygenase Activity in Male and Female Rats

\begin{tabular}{|c|c|c|c|c|}
\hline Treatment & $\frac{\text { Time }}{(\mathrm{d})}$ & $\frac{\text { Aminopyrine demethylase }}{(\mathrm{nmol} / \mathrm{mg} \text { protein } / \mathrm{min})}$ & $\frac{\text { Cytochrome } \mathrm{P}-450}{\text { (nmol/mg protein) }}$ & $\frac{\text { Heme oxygenase }}{(\mathrm{nmol} / \mathrm{mg} \text { protein } / \mathrm{h})}$ \\
\hline \multicolumn{5}{|l|}{$\left.\mathrm{BCG}^{a}\right)$} \\
\hline$\sigma$ Control & 3 & $6.300 \pm 0.204$ & $0.821 \pm 0.003$ & $0.606 \pm 0.031$ \\
\hline Treated & & $\left.5.270 \pm 0.085^{b}\right)(84)$ & $\left.0.733 \pm 0.005^{b}\right)(89)$ & $\left.1.173 \pm 0.077^{b}\right)(194)$ \\
\hline q Control & 3 & $4.719 \pm 0.136$ & $0.541 \pm 0.003$ & $0.704 \pm 0.004$ \\
\hline Treated & & $\left.2.632 \pm 0.219^{b}\right)(56)$ & $\left.0.391 \pm 0.001^{b}\right)(72)$ & $\left.2.291 \pm 0.089^{b}\right)(325)$ \\
\hline Control & 6 & $6.045 \pm 0.056$ & $0.852 \pm 0.002$ & $0.609 \pm 0.042$ \\
\hline Treated & & $\left.3.995 \pm 0.259^{b}\right)(66)$ & $\left.0.651 \pm 0.036^{b}\right)(76)$ & $\left.1.121 \pm 0.029^{b}\right)(184)$ \\
\hline q Control & 6 & $4.668 \pm 0.266$ & $0.579 \pm 0.003$ & $0.731 \pm 0.071$ \\
\hline $\begin{array}{l}\text { Treated } \\
\mathrm{CP}^{a)}\end{array}$ & & $\left.2.236 \pm 0.303^{b}\right)(48)$ & $0.347 \pm 0.014^{b)}(60)$ & $\left.2.089 \pm 0.293^{b}\right)(286)$ \\
\hline$\sigma^{\pi}$ Control & 3 & $6.518 \pm 0.006$ & $0.827 \pm 0.025$ & $0.675 \pm 0.002$ \\
\hline Treated & & $5.945 \pm 0.054^{b)}(91)$ & $\left.0.715 \pm 0.142^{b}\right)(86)$ & $\left.0.922 \pm 0.101^{b}\right)(137)$ \\
\hline q Control & 3 & $4.273 \pm 0.020$ & $0.609 \pm 0.011$ & $0.758 \pm 0.017$ \\
\hline Treated & & $2.418 \pm 0.034^{b)}(57)$ & $\left.0.427 \pm 0.016^{b}\right)(70)$ & $\left.2.017 \pm 0.200^{b}\right)(266)$ \\
\hline$\sigma^{\top}$ Control & 6 & $6.373 \pm 0.027$ & $0.843 \pm 0.003$ & $0.871 \pm 0.087$ \\
\hline Treated & & $\left.5.855 \pm 0.003^{b}\right)(92)$ & $\left.0.676 \pm 0.001^{b}\right)(80)$ & $\left.1.183 \pm 0.067^{b}\right)(136)$ \\
\hline q Control & 6 & $4.018 \pm 0.029$ & $0.647 \pm 0.001$ & $0.817 \pm 0.008$ \\
\hline Treated & & $3.045 \pm 0.034^{b)}(76)$ & $\left.0.504 \pm 0.011^{b}\right)(78)$ & $\left.1.586 \pm 0.158^{b}\right)(194)$ \\
\hline
\end{tabular}

Each value is the mean $\pm S . E$. of four rats. Figures in parentheses represent difference (\%).

a) Male and female Sprague-Dawley rats, weighing $156 \pm 3 \mathrm{~g}$, were injected i.v. at a dose of $40 \mathrm{mg} / \mathrm{kg}$ $B C G$ or $30 \mathrm{mg} / \mathrm{m}^{2} \mathrm{CP}$ and sacrificed at 3 or $6 \mathrm{~d}$ after the treatment. ferent from the corresponding control. 
in mice treated with Corynebacterium parvum, Cancer Res., 36, 4425-4428 (1976).

6) L. F. Soyka, C. C. Stephens, B. R. MacPherson and R. S. Foster: Role of mononuclear phagocytes in decreased hepatic drug metabolism following administration of Corynebacterium parvum, Int. J. Immunopharmac., 1, $101-112$ (1979).

7) G. Sonnenfeld, C. L. Harned, S. Thaniyavarn, T. Huff, A. D. Mandel and D. E. Nerland: Type II interferon induction and passive transfer depress the murine cytochrome P-450 drug metabolism system, Antimicrob. Agents Chemother., 17,969-972 (1980).

8) K. W. Renton and G. J. Mannering: Depression of hepatic cytochrome P-450-dependent monooxygenase systems with administered interferon inducing agents, Biochem. Biophys. Res. Commun., 73, 343-348 (1976).

9) G. Singh and K. Renton: Interferon-mediated depression of cytochrome P-450-dependent drug biotransformation, Mol. Pharmacol., 20,681-684 (1981).

10) A. Trescec, S. Iskric, I. Hrsak and J. Tomasic: Effect of immunoadjuvant peptidoglycan monomer on liver cytochrome P-450, Biochem. Pharmacol., 32, 2354-2357 (1983).

11) R. E. Azhary and G. J. Mannering: Effects of interferon inducing agents (Polyriboinosinic acid, Polyribocytidylic acid, Tilorone) on hepatic hemoproteins (cytochrome P-450, catalase, tryptophan 2,3-dioxygenase, mitochondrial cytochromes), heme metabolism and cytochrom P-450-linked monooxygenase systems, Mol. Pharmacol., 15,698-707 (1979).

12) R. E. Azhary, K. W. Renton and G. J. Mannering: Effect of interferon inducing agents (Polyriboinosinic acid, Polyribocytidylic acid and Tilorone) on the heme turnover of hepatic cytocrome P-450, Mol. Pharmacol., 17,395-399 (1980).

13) T. Yoshida, M. Okamoto, H. Hojo, Y. Suzuki and Y. Hashimoto: Effect of host-mediating anti-tumor drugs on hepatic $\delta$-aminolevulinic acid synthetase and heme oxygenase activity in mice, Toxicol. Lett., 2, $123-128$ (1978).

14) H. Hojo and Y. Hashimoto: Inhibition of drugmetabolizing enzymes in the mouse after treatment with host-mediating antitumor drugs, Toxicol. Lett., 1,89-93 (1977).

15) Y. Saino, J. Eda, T. Nagoya, Y. Yoshimura, M. Yamaguchi and F. Kobayashi: Anaerobic coryneforms isolated from human bone marrow and skin, Jpn. J. Microbiol., 20, 17-25 (1976).

16) R. Tenhunen, H. S. Marver and R. Schmid: The enzymatic catabolism of hemoglobin: Stimulation of microsomal heme oxygenase by hemin, J. Lab. Clin. Med., 75, 410-421 (1970).
17) H. S. Marver, D. P. Tschudy, M. G. Perlroth and A. Collins: $\delta$-Aminolevulinic acid synthetase J. Biol. Chem., 241, 2803-2809 (1966).

18) G. Urata and S. Granick: Biosynthesis of $\alpha$ aminoketones and the metabolism of aminoacetone, $J$. Biol. Chem., 238,811-817 (1963).

19) T. Omura and R. Sato: The carbon monoxide-binding pigment of liver microsomes, J. Biol. Chem., 239, $2370-2378$ (1964).

20) J. Cochin and J. Axelrod: Biochemical and pharmacological changes in the rat following chronic administration of morphine, nalorphine and normorphine, $J$. Pharmacol. Exp. Ther., 125,105-110 (1959).

21) T. Nash: The colorimetric estimation of formaldehyde by means of the Hantzsch reaction, Biochem. J., 55, 416-421 (1953).

22) Y. Imai, A. Ito and R. Sato: Evidence for biochemically different types of vesicles in the hepatic microsomal fraction, J. Biochem. (Tokyo), 60, 417-428 (1966).

23) O. H. Lowry, N. J. Resebrough, A. L. Farr and R.J. Randall: Protein measurement with the folin phenol reagent, J. Biol. Chem., 193,265-275 (1951).

24) J. U. Gutterman, G. Mavligit, J. A. Gottlieb, M. A. Burgess, C. E. McBride, L. Einhorn, E. J. Freireich and E. M. Hersh: Chemoimmunotherapy of disseminated malignant melanoma with dimethyl triazeno imidazole carboxamide and Bacillus Calmette-Guerin, N. Engl. J. Med., 291, 592-597 (1974).

25) M. D. Maines and A. Kappas: Studies on the mechanism of haem oxygenase by cobalt and other metal ions, Biochem. J., 154, 125-131 (1976).

26) Y. Matsuura, Y. Takizawa, T. Fukuda, T. Yoshida and $Y$. Kuroiwa: Induction of heme oxygenase and inhibition of $\delta$-aminolevulinic acid synthetase of rat liver by thioacetamide and thioacetamide-S-oxide, $J$. Pharmacobio-Dyn., 6, 340-345 (1983).

27) Y. Matsuura, H. Watanabe, T. Fukuda, T. Yoshida and Y. Kuroiwa: Alterations of hepatic $\delta$-aminolevulinic acid synthetase, heme oxygenase, microsomal cytochrome content and drug metabolism in rat bearing ascitic tumors AH 13, AH 66 and $\mathrm{AH} 414$ and a 3methylcholanthrene induced tumor, J. PharmacobioDyn., 7, 501 - 510 (1984).

28) T. Yoshida, M. Arakaki, J. Kumakawa and Y. Kuroiwa: An induction of heme oxygenase and its possible relation to the decrease of cytochrome P-450 during liver regeneration, J. Pharmacobio-Dyn., 7, 112-119 (1984).

29) J. R. Means and R. C. Schnell: Cadmium-induced alteration of the microsomal monooxygenase system in male rat liver: Effects on hemoprotein turnover and phospholipid content, Toxicol. Lett., 3, 177-184 (1979). 